\title{
A survey of Calliphoridae and Mesembrinellidae (Diptera) in semideciduous seasonal forest, Paraná, Brazil
}

\author{
Alex Sandro Barros de Souza ${ }^{1 *}$ \\ Marcos Magalhães de Souza ${ }^{2}$ \\ Patrícia Pereira Gomes ${ }^{1}$ \\ Jean Victor Nery da Silva ${ }^{1}$ \\ Giuliano Kaulfuss Bertinoti ${ }^{1}$ \\ José Adolfo Mota de Almeida ${ }^{1}$ \\ ${ }^{1}$ Instituto Federal de Educação, Ciência e Tecnologia do Paraná, Campus Umuarama \\ Rodovia PR 323, KM 310, Parque Industrial, CEP 87.507014, Umuarama - PR, Brasil \\ ${ }^{2}$ Instituto Federal de Educação, Ciência e Tecnologia do Sul de Minas Gerais, Campus Inconfidentes \\ Inconfidentes - MG, Brasil \\ * Autor para contato \\ alex.desouza@ifpr.edu.br
}

Submetido em 11/09/2020

Aceito para publicação em 18/12/2020

\section{Resumo}

Um levantamento de Calliphoridae e Mesembrinellidae (Diptera) em Floresta Estacional Semidecidual, Paraná, Brasil. Calliphoridae e Mesembrinellidae incluem espécies de Diptera que são bons indicadores de alterações em ambientes florestais. O presente trabalho objetivou inventariar a fauna de Calliphoridae e Mesembrinellidae no Parque Nacional da Ilha Grande, bem como correlacionar a abundância desses organismos às variáveis ambientais. Os dípteros foram coletados em duas campanhas em 2019, utilizando dois métodos de coleta: armadilha Malaise e armadilhas atrativas, distribuídas em duas ilhas do Parque. Foram coletados 1.007 indivíduos de 12 espécies de Calliphoridae e quatro espécies de Mesembrinellidae. A família Calliphoridae foi mais abundante, $97,12 \%$. A abundância das espécies nativas apresentou forte correlação negativa com a abundância do gênero Chrysomya. A Ilha Rodrigues (Ilha I) apresentou maiores índices de diversidade, e não foram registradas espécies do gênero Chrysomya, o que pode indicar maior grau de preservação do ambiente. Esses resultados revelam indícios que a ação humana em ambientes naturais pode impactar negativamente a diversidade de espécies, como no Parque Nacional de Ilha Grande que, historicamente teve grande parte de sua área ocupada e ainda se encontra em processo de regeneração.

Palavras-chave: Calyptratae; Chrysomya; Diversidade; Mata Atlântica; Varejeiras

\section{Abstract}

Calliphoridae and Mesembrinellidae include Diptera species that are good indicators of changes in forest environments. The present work aimed to inventory the Calliphoridae and Mesembrinellidae in Ilha Grande National Park and correlate the abundance of these organisms with environmental variables. Adult dipterans 
were collected during two expeditions in 2019 using two sampling methods, a Malaise trap and baited traps, distributed on two islands in the park. During the study, 1,007 individuals of 12 species of Calliphoridae and four species of Mesembrinellidae were collected. Family Calliphoridae was more abundant (97.12\%). The abundance of native species showed a strong negative correlation with the abundance of the genus Chrysomya. Rodrigues Island (Island I) had higher diversity levels and no species of Chrysomya were recorded in this area, which may indicate a greater degree of environmental preservation. The results indicate that human action in natural environments can negatively impact species diversity, as found in Ilha Grande National Park that, historically, was partially occupied and is still in the process of regeneration.

Key words: Atlantic Forest; Blowflies; Calyptratae; Chrysomya; Diversity

\section{Introduction}

The insect family Calliphoridae (Diptera, Oestroidea) is cosmopolitan, popularly known as blowflies and comprises more than 1,500 species (PAPE et al., 2011), of which approximately 60 species occur in the neotropical region (KOSMANN et al., 2013). The larvae of most species develop in decomposing organic matter and some species are reported to cause myiasis (GUIMARÃES; PAPAVERO, 1999). Due to the fact that immatures use decomposing organic matter, many species are extremely important for forensic entomology, since they can be used to calculate the post-mortem interval and even indicate the place of death (AMENDT et al., 2004). When adults, many Calliphoridae species act as pollinators (SAEED et al., 2016).

Calliphoridae species have different degrees of tolerance to environmental conditions and, therefore, are very affected by human impact in natural environments (SOUSA et al., 2014). Thus, from a conservation point of view, fly communities are directly affected by both environmental degradation and exotic species (CARMO; VASCONCELOS, 2016). As a result, they are excellent indicators of anthropogenic impacts, as well as indicators of forest regeneration and conservation degree (SOUSA et al., 2014).

The fly family Mesembrinellidae (Diptera, Oestroidea), in turn, is exclusively neotropical (WHITWORTH; YUSSEFF-VANEGAS, 2019). For many years, this group was treated as a subfamily of Calliphoridae; however, numerous taxonomic and developmental differences allowed it to be separated (GUIMARÃES, 1977). Females of Mesembrinellidae produce one egg at a time that hatches into a larva while still inside the uterus, which is then deposited on the substrate (VARGAS; WOOD, 2010). Additionally, species of Mesembrinellidae are more robust than Calliphoridae, with a metallic abdomen and brown chest (WHITWORTH; YUSSEFF-VANEGAS, 2019). This group has a distribution restricted to forests and preserved environments (MELLO et al., 2007). Thus, due to these characteristics, Mesembrinellidae species are excellent bioindicators of preserved areas (GADELHA et al., 2009).

In recent years, forest environments in practically all states of Brazil have suffered from an intense devastation process that has increasingly decreased the amount of preserved area (SCHIELEINA; BÖRNERA, 2018; NASSER et al., 2019). The expansion of urban areas into natural environments causes the destruction of countless habitats of different species (PIGNATARO et al., 2020). In general, an increase in the anthropization level decreases insect species diversity (MARINONI; GANHO, 2006; FERRAGUTI et al., 2016) and, therefore, it is important to recognize the entomofauna of certain areas to monitor the impacts of anthropic action in these communities (HALLMANN et al., 2017). In addition, local biodiversity loss directly affects humans, both in terms of health and economically (CRUZ et al., 2020). In this context, zoological inventories aim mainly to know which species make up the analyzed communities and, thus, provide necessary data for fauna conservation and management (SILVEIRA et al., 2010).

Therefore, this study aimed to inventory the Calliphoridae and Mesembrinellidae of Ilha Grande National Park and correlate the abundance of the two families with environmental variables in the region. 


\section{Materials and Methods}

Ilha Grande National Park (53०41'09.2", $23^{\circ} 16^{\prime} 32^{\prime \prime}$ S and $54^{\circ} 16^{\prime} 21.7^{\prime \prime} \mathrm{W}, 2^{\circ} 04^{\prime} 11.5^{\prime}$ 'S) includes several islands in the Paraná River on the border between the states of Paraná and Mato Grosso do Sul, Brazil. The phytophysiognomy of the park has characteristics of seasonal semideciduous alluvial forest, as well as submontane and dense ombrophilous forest of the Atlantic Forest domain, which can be classified macro-regionally as a transition zone between the Atlantic Forest and Cerrado (CAMPOS, 2001; IBGE, 2012). The park has an average temperature of $22^{\circ} \mathrm{C}$, annual precipitation of 1,200 to $1,300 \mathrm{~mm}$ and a humid subtropical mesothermal climate (Cfa) with a hot summer, according to the Köeppen-Geiger system (CAMPOS, 2001).

The study, authorized by ICMBio through the license SISBIO 65047-1, was conducted in February and November 2019 and included two collection expeditions that totaled about 10 days of sampling. Collections were made on two islands (Figure 1) in the southern region of Ilha Grande National Park: Rodrigues

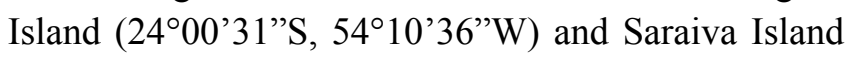

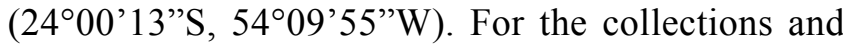
statistical analysis, the islands were identified as the following: Rodrigues Island = Island I; and Saraiva Island $=$ Island II.

Two collection methods were used to maximize the number of species collected: i) a Malaise trap (MI) modified according to Duarte et al. (2010) (a single trap was set up only on Island I on the first day of collection and removed on the last day); and ii) traps made from polyethylene bottles (PET) following the model proposed by Mello et al. (2007). On each island, 15 PET traps were set up, $150 \mathrm{~m}$ apart from each other and $1.5 \mathrm{~m}$ from the ground, containing ground beef as an attractive substrate that was removed from refrigeration $24 \mathrm{~h}$ before collecting began. The data obtained from the PET bottle method, used on islands I and II, were grouped into a single item. Thus, Group I (GI) corresponds to the total of PET traps on Island I and Group II (GII) corresponds to the total of PET traps on

FIGURE 1: Map of the islands where the traps were installed to capture Calliphoridae and Mesembrinellidae species in Ilha Grande National Park, Paraná.

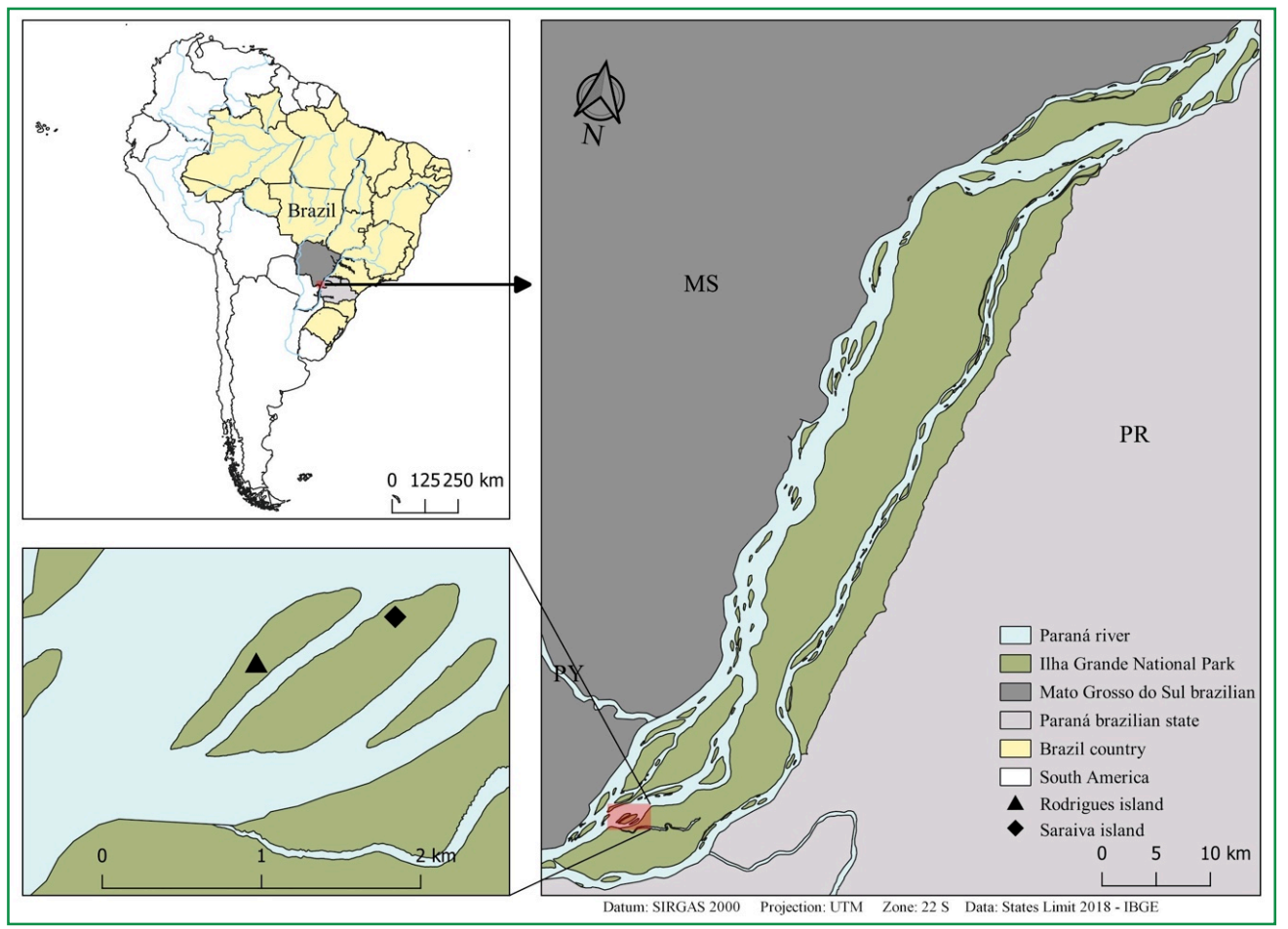


Island II. The analysis of fauna diversity was performed for each collection method using Shannon, Simpson, Margalef and equitability indices.

The correlation of species collected abundance with the average values for temperature, humidity and precipitation, of the four days when the traps were exposed during each expedition, was analyzed using Pearson's correlation according to the methodology proposed by Ferraz et al. (2010a). Based on this methodology, the abundance and precipitation values were transformed into a logarithm $(\mathrm{x}+1)$; $\mathrm{x}$ is the value of each of these variables. The correlation between Chrysomya species abundance and the abundance of the main species collected was also analyzed. For these analyses, only species with more than 15 individuals sampled were used. Climatological data were provided by the Climatological Station of the Paraná Meteorological System (SIMEPAR).

To verify the similarities between the collection methods, a cluster analysis was made using a similarity matrix (based on a presence/absence matrix) obtained by the Jaccard coefficient, and a dendrogram was made using the unweighted pair group method with arithmetic mean (UPGMA). All analyses in this study were conducted with the software PAST 3.2.4 (HAMMER et al., 2001).

The collected specimens were fixed in $70 \%$ alcohol and taken to the laboratory for screening and identification. The biological material was identified using the taxonomic keys in Kosmann et al. (2013), Whitworth (2014) and Whitworth and Yusseff-Vanegas (2019). Reference material was deposited in the didacticscientific collection at the Federal Institute of Paraná (IFPR), campus Umuarama.

\section{Results}

In total, 1,007 individuals (Table 1) were collected, including 12 species (six genera) of Calliphoridae and four species (two genera) of Mesembrinellidae.

TABLE 1: Distribution of individuals of each Calliphoridae and Mesembrinellidae species in the collection points, and percentage by sex, in Ilha Grande National Park. $0=$ absence and 1 = presence.

\begin{tabular}{lccccccc}
\hline Calliphoridae & AF & RF (\%) & F (\%) & M (\%) & GI & GII & MI \\
\hline Chrysomya albiceps (Wiedemann, 1819) & 529 & 53.4 & 94.1 & 5.9 & 1 & 0 & 1 \\
Chrysomya megacephala (Fabricius, 1794) & 311 & 30.7 & 60.5 & 39.5 & 1 & 0 & 1 \\
Chrysomya putoria (Wiedemann, 1818) & 11 & 1.0 & 63.6 & 36.4 & 1 & 0 & 1 \\
Cochliomyia macellaria (Fabricius, 1775) & 5 & 0.3 & 80 & 20 & 0 & 1 & 1 \\
Cochliomyia hominivorax (Coquerel, 1858) & 1 & 0.1 & 100 & 0 & 0 & 0 & 1 \\
Chloroprocta idioidea (Robineau-Devoidy, 1830) & 7 & 0.7 & 85.7 & 14.3 & 0 & 0 & 1 \\
Hemilucilia segmentaria (Fabricius, 1805) & 28 & 2.8 & 53.6 & 46.4 & 0 & 1 & 1 \\
Hemilucilia semidiaphana (Rondani, 1850) & 18 & 1.7 & 55.6 & 44.4 & 1 & 1 & 1 \\
Lucilia cuprina (Wiedemann, 1830) & 4 & 0.3 & 50 & 50 & 1 & 0 & 1 \\
Lucilia eximia (Wiedemann, 1819) & 46 & 4.6 & 57.5 & 42.5 & 1 & 1 & 1 \\
Lucilia sericata (Meigen, 1826) & 8 & 0.8 & 62.5 & 37.5 & 1 & 0 & 1 \\
Paralucilia pseudolyrcea (Mello, 1969) & 15 & 1.5 & 53.3 & 46.7 & 0 & 1 & 1 \\
\hline Mesembrinellidae & & & & & & & 0 \\
\hline Lanella nigripes Guimarães, 1977 & 3 & 0.3 & 75 & 25 & 0 & 1 & 0 \\
Mesembrinella bicolor (Fabricius, 1805) & 2 & 0.2 & 100 & 0 & 0 & 1 & 0 \\
Mesembrinella semihyalina Mello, 1967 & 7 & 0.7 & 78.6 & 21.4 & 0 & 1 & 1 \\
Mesembrinella bellardiana Aldrich, 1922 & 8 & 0.8 & 66.7 & 33.3 & 0 & 1 & 1 \\
\hline
\end{tabular}

$\mathrm{AF}=$ Absolute Frequency; RF = Relative Frequency; $\mathrm{M}=$ Male; $\mathrm{F}=$ Female; $\mathrm{MI}=$ Malaise trap Island I; GI = PET trap Island I; GII = PET trap Island II. 
Calliphoridae correspond to $97.12 \%$ of the collected material. In addition, blowflies correspond to the largest portion of fauna observed for all collection methods (Table 2) and all sampled environments. However, Chrysomya albiceps and Chrysomya megacephala correspond to $53.4 \%$ and $30.7 \%$ of the total individuals collected, respectively.
For the diversity indices (Table 3), Group II (GII) had the highest values in all indices used, while Group I (GI) had the lowest values in the same indices. The similarity analysis (Figure 2) formed a GII+MI group with low similarity (0.41). The total abundance of species was correlated with climatic variables in only one situation (Table 4), the GI that had a strong negative correlation

TABLE 2: Percentage of individuals of the Calliphoridae species * collected in Ilha Grande National Park in relation to the total number of individuals collected in each method.

\begin{tabular}{lccc}
\hline \multicolumn{1}{c}{ Taxon } & GI (\%) & GII (\%) & MI (\%) \\
\hline Chrysomya albiceps & 65.5 & 0 & 34.9 \\
Chrysomya megacephala & 32.7 & 0 & 31.4 \\
Hemilucilia segmentaria & 0 & 22.2 & 5.9 \\
Hemilucilia semidiaphana & 0.5 & 15.5 & 2.6 \\
Lucilia eximia & 0.1 & 34.4 & 8.6 \\
Paralucilia pseudolyrcea & 0 & 9.8 & 3.8 \\
\hline
\end{tabular}

MI = Malaise trap Island I; GI = PET trap Island I; GII = PET trap Island II; * species with more than 15 individuals were selected.

TABLE 3: Total diversity indices of species collected in Ilha Grande National Park by each method.

\begin{tabular}{lccc}
\hline \multicolumn{1}{c}{ Index } & GI & GII & MI \\
\hline Simpson_1-D & 0.4741 & 0.8629 & 0.742 \\
Shannon_H & 0.7856 & 2.205 & 1.732 \\
Margalef & 0.925 & 2.525 & 2.293 \\
Equitability_J & 0.4037 & 0.8872 & 0.6562 \\
\hline
\end{tabular}

MI = Malaise trap Island I; GI = PET trap Island I; GII = PET trap Island II.

FIGURE 2: Dendrogram of similarity between the methods used. MI = Malaise trap Island I; G I = PET trap Island I; G II = PET trap Island II.

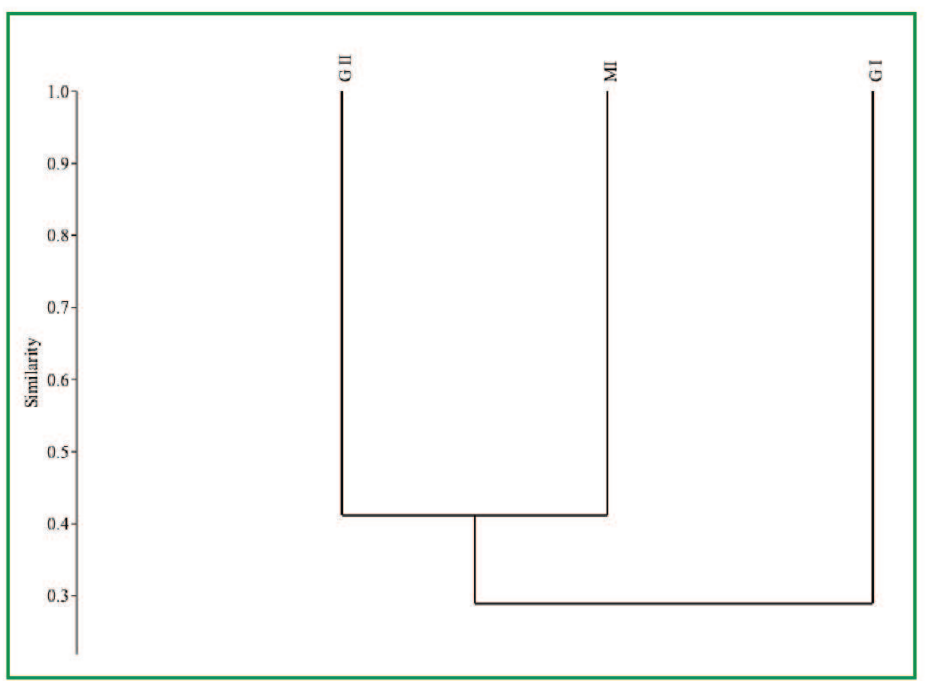


TABLE 4: Pearson's correlation indeces of total species abundance in each method in relation to climatic variables.

\begin{tabular}{cccc}
\hline \multirow{2}{*}{ Method } & \multicolumn{3}{c}{ Climate Variable } \\
\cline { 2 - 4 } & Precipitation & Temperature & Relative Humidity \\
\hline GI & -0.690 & 0.408 & 0.501 \\
GII & -0.375 & 0.527 & -0.392 \\
MI & 0.486 & -0.279 & 0.429 \\
\hline
\end{tabular}

$\mathrm{MI}=$ Malaise trap Island I; GI = PET trap Island I; GII = PET trap Island II.

$(\mathrm{r}=-0.690)$ with precipitation. In the remaining cases, no correlation was found between abundance and climatic variables. For the individual species analysis (Table 5), no species showed a correlation with precipitation and only Lucilia eximia was correlated with relative air humidity. Only Chrysomya albiceps and Chrysomya megacephala were correlated with temperature. The correlation analysis of Chrysomya abundance with the abundance of the main species collected had a strong negative correlation for all analyzed species (Table 6).

\section{Discussion}

The absence or low correlation between Calliphoridae species abundance and the climatic variables observed in this work was also found in previous studies (MELLO et al., 2007; FERRAZ et al., 2010a). In addition, it is common to find regionalized population fluctuations in the group (PARALUPPI; CASTELLÓN, 1994; VIANNA et al., 2004), which could indicate that biotic factors might be more decisive in relation to distribution. However, when analyzed separately, the genus Chrysomya showed a strong positive correlation with temperature. This indicates that with rising temperatures, due to imminent climate change, there is a strong tendency for fly communities to be affected. Furthermore, since this genus has a short development time compared to native species, a temperature rise can lead to an increase in invasive species abundance and, therefore, native species exclusion.

This study also reports three new records for the South Region of Brazil: i) Laneella nigripes that only had records for the Southeast Region of the country

TABLE 5: Pearson's correlation indices of total species abundance for each method in relation to climatic variables.

\begin{tabular}{lccc}
\multicolumn{1}{c}{ Taxon } & Precipitation & Temperature & Relative Humidity \\
Chrysomya albiceps & 0.459 & 0.825 & 0.326 \\
Chrysomya megacephala & 0.390 & 0.818 & 0.109 \\
Hemilucilia segmentaria & 0.019 & 0.193 & -0.455 \\
Hemilucilia semidiaphana & 0.190 & 0.022 & 0.419 \\
Lucilia eximia & 0.212 & 0.345 & -0.660 \\
Paralucilia pseudolyrcea & 0.011 & 0.201 & 0.340 \\
\hline
\end{tabular}

* species with more than 15 individuals were selected.

TABLE 6: Pearson's correlation indeces of the abundance of the Chrysomya genus in relation to the other species.

\begin{tabular}{lccccc}
\hline & $\begin{array}{c}\text { Chrysomya } \\
\text { megacephala }\end{array}$ & $\begin{array}{c}\text { Hemilucilia } \\
\text { segmentaria }\end{array}$ & $\begin{array}{c}\text { Hemilucilia } \\
\text { semidiaphana }\end{array}$ & $\begin{array}{c}\text { Lucilia } \\
\text { eximia }\end{array}$ & $\begin{array}{c}\text { Paralucilia } \\
\text { pseudolyrcea }\end{array}$ \\
\hline Chrysomya albiceps & 0.975 & -0.770 & -0.912 & -0.925 & -0.762 \\
Chrysomya megacephala & - & -0.609 & -0.798 & -0.818 & -0.600 \\
\hline
\end{tabular}


(MARINHO et al., 2017; WHITWORTH; YUSSEFFVANEGAS, 2019); ii) Mesembrinella semihyalina, which had records for the Southeast, North and Northeast regions (MARINHO et al., 2017; WHITWORTH; YUSSEFF-VANEGAS, 2019); and iii) Chloroprocta idioidea, which only had records for the North, Northeast, Southeast and Central-West regions (BATISTA-DASILVA et al., 2010; URURAHY-RODRIGUES et al., 2013; SOUSA et al., 2014; KOSMANN et al., 2017). Considering the relatively short exposure period of the Malaise trap, as well as PET bottle traps, this study collected a significant number of species.

Although family Calliphoridae is relatively well studied, its fauna in Paraná is still poorly known. The first record was a study about synanthropy by Ferreira (1978) that listed eight species for Curitiba. Subsequently, Moura et al. (1997) and Caleffe et al. (2015) recorded three species of Calliphoridae each, in studies focusing on forensic entomology. The other species records of this family in Paraná are in taxonomic revisions (WHITWORTH, 2014; MARINHO et al., 2017; WHITWORTH; YUSSEFF-VANEGAS, 2019).

Together, Chrysomya albiceps and Chrysomya megacephala make up about $83 \%$ of the total collected individuals. In addition, all of the Chrysomya individuals were collected on Island I, which can be explained by the fact that this island has greater remnants of anthropization, such as abandoned houses, remnants of fruit tree plantations, and the presence of a family of resident islanders. Since the 1950s, and before the park was delimited in 1997, many islands were occupied and used for housing, summer vacation and agriculture (ROSA, 1997; MOTTA; CAMPOS, 2001). The genus Chrysomya was introduced to Brazil in the 1970s (GUIMARÃES et al., 1978). Invasive species in the group quickly spread throughout the country; they are highly synanthropic species and very well adapted to human environments (FERRAZ et al., 2010a). On the other hand, no individuals of this genus were collected on Island II, which may indicate a greater degree of preservation in this area.

Lucilia was the second most abundant genus in the present study. Three species were sampled: Lucilia cuprina, Lucilia sericata and Lucilia eximia. The first two are invasive species and the last is exclusive to the New World. Although L. eximia has been suffering from the impacts of invasive species in recent years, it is still well distributed in Brazil (FERRAZ et al., 2010b; CARMO; VASCONCELOS, 2016). It can be inferred that with a greater collection effort in the country, the known richness of Lucilia would increase because, in review of the genus, Whitworth (2014) described four new species for Brazil.

Cochliomyia macellaria is a neotropical species, while Cochliomyia hominivorax is a species that causes myiasis and is easily collected in urban environments (GUIMARÃES; PAPAVERO, 1999). Both species are relatively common in Brazil and a previous study found that Chrysomya albiceps tends to prefer preying on Cochliomyia macellaria larvae over other studied species (FARIA et al., 1999).

Paralucilia pseudolyrcea is a wild neotropical species that has two synonyms: Myolucilia lyrcea (KOSMANN et al., 2013) and Paralucilia xanthogeneiates (MADEIRA-OTT et al., 2019). The first had already been observed by Ferreira (1978) in Paraná State and the second has been recorded in the three southern states of Brazil (CARVALHO; RIBEIRO, 2000). Chloroprocta idioidea also has a wide distribution in Brazil, based on fauna and forensic entomology studies (FERRAZ et al., 2010b; URURAHY-RODRIGUES et al., 2013), and occurs in wild areas with varied phytophysiognomies. However, there were no records for Paraná State, although there were records in nearby regions, such as Mato Grosso do Sul State (KOSMANN et al., 2017) and Paraguay (DEAR, 1985).

Hemilucilia segmentaria and Hemilucilia semidiaphana, observed in this study, are also native species commonly found throughout Brazil, generally in forest environments (FERRAZ et al., 2010b; URURAHY-RODRIGUES et al., 2013).

Regarding the family Mesembrinellidae, four species were collected, with most of the material coming from Island II. In the case of Island I, all collected individuals came from the Malaise trap. The species in this family are exclusive to the neotropical region, characterized as asynanthropic and are commonly 
collected in preserved environments (CABRINI et al., 2013). The absence of individuals in the group GI traps can be explained by two factors: i) the high abundance of the genus Chrysomya, which may have excluded Mesembrinellidae individuals; and ii) this area has the most pronounced anthropogenic action, and the species of this family are more sensitive to habitat disturbance (GADELHA et al., 2009; CABRINI et al., 2013).

The traps of the GII group and GI group had a very low degree of similarity. Moreover, GI had low diversity in all indices used. This pattern can be explained by the low abundance of the genus Chrysomya found on Island II, since Chrysomya specimens were not collected in GII traps. On the other hand, in the GI traps the genus Chrysomya exhibited high abundance. This, added to the fact that all native species showed a high negative correlation with species of Chrysomya, may explain the patterns found in this study; especially because Chrysomya species are highly excluding, since they have a shorter development time in relation to native species that makes them excellent competitors. MI and GII were more similar, although the similarity (below 0.50 ) was low. According to Kent and Coker (1992), only values equal to or greater than 0.50 can be considered as high similarity. The degree of similarity between MI and GII can be explained by the Jaccard index evaluating the similarity qualitatively. Thus, this index analyzes the proportion of species shared among the samples in relation to the total number of species. In this case, the index does not consider the number of individuals present in the sample, but their presence and absence (FERREIRA et al., 2008).

Furthermore, in the PET traps an attractive substrate was used. This could explain the high abundance of Chrysomya and is a strong exclusion factor for other species due to the predatory character of immatures of this genus that, in some cases, can practice cannibalism (FARIA et al., 2004). Thus, native species tend to choose substrates for laying eggs where immature Chrysomya do not occur (GALINDO et al., 2016; SPINDOLA et al., 2017). This exclusion becomes evident because necrophagous species use ephemeral resources and tend to have an aggregate distribution (MOURA, 2004), so the competition for substrate becomes inevitable. An increase of invasive species in neotropical environments, with the consequent decrease in native species, has already been observed for islands (CARMO; VASCONCELOS, 2016), coastal regions (BARBOSA et al., 2017), the Atlantic Forest (FERRAZ et al., 2010b) and the Chaco ecoregion (DUFEK et al., 2019).

Based on this, the results highlight that human action can play a decisive role in the diversity of species. This is because environmental degradation and/or urbanization can contribute positively to the dispersal of invasive species, especially in combination with temperature rise due to climate change, which increases the abundance of exotic species and, consequently, decreases species diversity. These data draw attention to new challenges in terms of land use and conservation. If natural areas continue to be degraded, native species must be monitored and/or included in management programs so they do not go extinct.

\section{Acknowledgments}

We thank the following: ICMBio for the research permits (SISBIO n ${ }^{\circ}$ 65047-1); the Paraná Meteorological System (SIMEPAR) for providing the climatological data; the environmental analysts and brigade members of ICMBio for their assistance in the collecting logistics in Ilha Grande National Park, Paraná State; and the members of the field team who assisted with data collection (Diego Santiago, Mariane Peczek and Lucas Rodrigues).

\section{References}

AMENDT, J.; ZEHNER, R.; KRETTER, R. Forensic entomology. Naturwissenschaften, Heidelberg, v. 91, p. 51-56, 2004.

BARBOSA, T. M.; CARMO, R. F. R.; SILVA, L. P.; SALES, R. G.; VASCONCELOS, S. D. Diversity of sarcosaprophagous calyptratae (Diptera) on sandy beaches exposed to increasing levels of urbanization in Brazil. Environmental Entomology, Lanham, v. 46, n. 3, p. 460-469, 2017.

BATISTA-DA-SILVA, J. A.; MOYA-BORJA, G. E.; QUEIROZ, M. M. C. Ocorrência e sazonalidade de muscóides (Diptera, Calliphoridae) de importância sanitária no município de Itaboraí, RJ, Brasil. EntomoBrasilis, Vassouras, v. 3, n. 1, p. 16-21, 2010 . 
CABRINI, I.; GRELLA, M. D.; ANDRADE, C. F. S.; THYSSEN, P. J. Richness and composition of Calliphoridae in an Atlantic Forest fragment: Implication for the use of dipteran species as bioindicators. Biodiversity and Conservation, New York, v. 22, p. 2635-2643, 2013.

CALEFFE, R.; OLIVEIRA, S.; NANYA, S.; CONTE, H. Calliphoridae (Diptera) de interesse forense com ocorrência em Maringá-PR-Brasil. Revista Uningá, Maringá, v. 43, n. 1, p. 1-6, 2015.

CAMPOS, J. B. Caracterização física e ambiental da área do Parque Nacional de Ilha Grande. In: CAMPOS, J. B. (Ed.). Parque Nacional de Ilha Grande: re-conquista e desafios. 2 ed. Maringá: Instituto Ambiental do Paraná, 2001. p. 1-10.

CARMO, R. F.; VASCONCELOS, S. D. Assemblage of necrophagous Diptera in Atlantic insular environments and response to different levels of human presence. Neotropical Entomology, Londrina, v. 45, n. 5, p. 471-481, 2016.

CARVALHO, C. J. B; RIBEIRO, P. B. Chave de identificação das espécies de Calliphoridae (Diptera) do Sul do Brasil. Revista Brasileira de Parasitologia Veterinária, Jaboticabal, v. 9, n. 2, p. 169-173, 2000.

CRUZ, D. C.; BENAYAS, J. M. R.; FERREIRA, G. C. An overview of forest loss and restoration in the Brazilian Amazon. New Forests, Sydney, 2020. Disponível em $<$ https://link.springer. com/content/pdf/10.1007/s11056-020-09777-3.pdf $>$.

DEAR, J. P. A revision of the new world Chrysomyini (Diptera: Calliphoridae). Revista Brasileira de Zoologia, Curitiba, v. 3, p. 109-169, 1985.

DUARTE, J.; KRÜGER, R.; DE-CARVALHO, C.; RIBEIRO, P. Evidence of the influence of Malaise trap age on its efficiency in the collection of Muscidae (Insecta, Diptera). International Journal of Tropical Insect Science, Cambridge, v. 30, n. 2, p. 115-118, 2010.

DUFEK, M. I; OSCHEROV, E. B.; DAMBORSKY, M. P.; MULIERI, P. R. Calliphoridae (Diptera) in human-transformed and wild habitats: diversity and seasonal fluctuations in the humid chaco ecoregion of South America. Journal of Medical Entomology, Lanham, v. 56, n. 3, p. 725-736, 2019.

FARIA, L. D. B.; ORSI, L.; TRINCA, L. A.; GODOY, W. A. C. Larval predation by Chrysomya albiceps on Cochliomyia macellaria, Chrysomya megacephala and Chrysomya putoria. Entomologia Experimentalis et Applicata, Dordrecht, v. 90, p. 149-155, 1999.

FARIA, L. D. B.; TRINCA, L. A.; GODOY, W. A. C. Cannibalistic behavior and functional response in Chrysomya albiceps (Diptera: Calliphoridae). Journal of Insect Behavior, New York, v. 17, p. 251-261, 2004.

FERRAGUTI, M.; MARTÍNEZ-DE LA PUENTE, J.; ROIZ, D.; RUIZ, S.; SORIGUER, R.; FIGUEROLA, J. Effects of landscape anthropization on mosquito community composition and abundance. Scientific Reports, London, v. 6, n. 29002, 2016.

FERRAZ, A. C. P.; GADELHA, B. Q.; AGUIAR-COELHO, V. M. Influência climática e antrópica na abundância e riqueza de Calliphoridae (Diptera) em fragmento florestal da Reserva Biológica do Tinguá, RJ. Neotropical Entomology, Londrina, v. 39, n. 4, p. 476-485, 2010a.
FERRAZ, A. C. P.; GADELHA, B. Q.; QUEIROZ, M. M. C.; MOYA-BORJA, G. E.; AGUIAR-COELHO, V. M. Effects of forest fragmentation on dipterofauna (Calliphoridae) at the Reserva Biológica do Tinguá, Nova Iguaçu, RJ. Brazilian Journal of Biology, São Carlos, v. 70, n. 1, p. 55-63, 2010 b.

FERREIRA, M. J. M. Sinantropia de dípteros muscóides de Curitiba, Paraná. I. Calliphoridae. Revista Brasileira de Biologia, São Carlos, v. 38, n. 2, p. 445-454, 1978.

FERREIRA, R. L. C.; MOTA, A. C.; SILVA, J.A.A.; MARANGON, L. C.; SANTOS, E. S. Comparação de duas metodologias multivariadas no estudo de similaridade entre fragmentos de Floresta Atlântica. Revista Árvore, Viçosa, v. 32, n. 3, p. 511-521, 2008.

GADELHA, B. Q.; FERRAZ, A. C. P.; AGUIAR-COELHO, V. M. A importância dos mesembrinelíneos (Diptera: Calliphoridae) e seu potencial como indicadores de preservação ambiental. Oecologia Brasiliensis, Rio de Janeiro, v. 13, n. 4, p. 660-664, 2009.

GALINDO, L. A.; MORAL, R. A.; MORETTI, T. C. Intraguild predation influences oviposition behavior of blow flies (Diptera: Calliphoridae). Parasitology Research, Heidelberg, v. 115, p. 2097-2102, 2016.

GUIMARÃES, J. H. A Systematic revision of the Mesembrinellidae, stat. nov. (Diptera, Cyclorrhapha). Arquivos de Zoologia, São Paulo, v. 29, n. 1, p. 1-109, 1977.

GUIMARÃES, J. H.; PAPAVERO, N. Myiasis in man and animals in the Neotropical region: bibliographic database. São Paulo: FAPESP/Editora Plêiade, 1999. 308 p.

GUimarÃES, J. H.; PRADO, A. P.; LINHARES, A. X. Tree newly introduced blowfly species in southern Brazil (Diptera, Calliphoridae). Revista Brasileira de Entomologia, Curitiba, v. 22, p. 53-60, 1978.

HALLMANN, C. A.; SORG, M.; JONGEJANS, E.; SIEPEL, H.; HOFLAND, N.; SCHWAN, H.; STENMANS, W.; MÜLLER, A.; SUMSER, H.; HÖRREN, T.; GOULSON, D.; KROON, H. More than 75 percent decline over 27 years in total flying insect biomass in protected areas. PLoS One, Cambridge, v. 12, n. 10, 2017. Disponível em <https://journals.plos.org/plosone/ article?id=10.1371/journal.pone.0185809\#ack>.

HAMMER, Ø.; HARPER, D. A. T.; RYAN, P. D. PAST: Paleontological Statistics Software package for education and data analysis. Palaeontologia Electronica, Oslo, v. 4, n. 1, p. 1-9, 2001. IBGE - INSTITUTO BRASILEIRO DE GEOGRAFIA E ESTATÍSTICA. Manual técnico da vegetação brasileira. 2012. Rio de Janeiro: IBGE. Disponível em: <https://biblioteca.ibge.gov. br/visualizacao/livros/liv63011.pdf >.

KENT, M.; COKER, P. Vegetation description analyses. London: Behaven Press, 1992. 363 p.

KOSMANN, C.; MELLO, R. P.; HARTERREITEN-SOUZA, E. S.; PUJOL-LUZ, J. R. A List of current valid blow fly names (Diptera: Calliphoridae) in the Americas South of Mexico with key to the Brazilian species. EntomoBrasilis, Vassouras, v. 6, n. 1, p. 74-85, 2013.

KOSMANN, C.; PRESTES, A. C.; TEPEDINO, K. P.; FRANCO, A. C.; PUJOL-LUZ, C. V. A.; PUJOL-LUZ, J. R. Lista das espécies 
de Calliphoridae (Diptera, Oestroidea) do Estado do Mato Grosso do Sul, Brasil. Iheringia, Série Zoologia, Porto Alegre, v. 107, e2017140, 2017.

MADEIRA-OTT, T.; MARINHO, M. A. T.; CORDEIRO, J.; THYSSEN, P. J. First molecular phylogeny of Paralucilia Brauer \& Bergenstamm, 1891 (Insecta, Diptera, Calliphoridae): a preliminary approach. Acta Tropica, Miami, v. 198, p. 105096, 2019.

MARINHO, M. A. T.; WOLFF, M.; RAMOS-PASTRANA, Y.; AZEREDO-ESPIN, A. M. L.; AMORIM, D. S. The first phylogenetic study of Mesembrinellidae (Diptera: Oestroidea) based on molecular data: clades and congruence with morphological characters. Cladistics, New York, v. 33, p. 134-152, 2017.

MARINONI, R. C.; GANHO, N. G. A Diversidade diferencial beta de Coleoptera (Insecta) em uma paisagem antropizada do bioma araucária. Revista Brasileira de Entomologia, Curitiba, v. 50, n. 1, p. 64-71, 2006.

MELlO, R. S.; QUEIROZ, M. M. C.; VAlGODE, M. A.; AGUIAR-COELHO, V. M. Population fluctuations of calliphorid species (Diptera, Calliphoridae) in the Biological Reserve of Tinguá, state of Rio de Janeiro, Brazil. Iheringia, Porto Alegre, v. 97, n. 4, p. 1-5, 2007.

MOTTA, M. N. J.; CAMPOS, J. B. Antecedentes históricos de proteção ambiental às ilhas e várzeas do rio Paraná. In: CAMPOS, J. B. (Ed.). Parque Nacional de Ilha Grande: re-conquista e desafios. Maringá: Instituto Ambiental do Paraná, 2001. p. 20-29.

MOURA, M. O. Variação espacial como mecanismo promotor da coexistência em comunidades de insetos necrófagos. Revista Brasileira de Zoologia, Curitiba, v. 21, n. 3, p. 409-419, 2004.

MOURA, M. O.; CARVALHO, C. J. B.; MONTEIRO-FILHO, E. L. A. A preliminary analysis of insects of medico-legal importance in Curitiba, state of Paraná. Memórias do Instituto Oswaldo Cruz, Rio de Janeiro, v. 92, n. 2, p. 269-274, 1997.

NASSER, N. P. A.; RAMOS, R. F.; SCHEEREN, N. B.; DALLA NORA, D.; BELLÉ, C.; BETEMPS, D. L. Germinação de sementes de Bromeliaantiacanthaem diferentes fotoperíodos. Revista Eletrônica Científica da UERGS, Porto Alegre, v. 5, n. 3, p. 296301, 2019.

PAPE, T.; BLAGODEROV, V.; MOSTOVSKI, M. B. Order Diptera Linnaeus, 1758. In: ZHANG, Z. Q. (Ed.) Animal biodiversity: an outline of higher-level classification and survey of taxonomic richness. Zootaxa, Auckland, v. 3148, n. 1, p. 222-229, 2011.

PARALUPPI, N. D.; CASTELLÓN, E. G. Calliphoridae (Diptera) em Manaus: I levantamento taxonômico e sazonalidade. Revista Brasileira de Entomologia, Curitiba, v. 38, p. 661-668 1994.

PIGNATARO, T.; BRESSAN, P.; SANTOS, A. L.; CORNELISSEN, T. Urban gradients alter the diversity, specific composition and guild distribution in tropical butterfly communities. Urban Ecosystems, New York, v. 23, p. 723-730, 2020.
ROSA, M. C. Domínio socioeconômico: processo de ocupação e situação atual. In: VAZZOLER, A. E. A. M.; AGOSTINHO, A. A.; HAHN, N. S. (Ed.). A planície de inundação do alto rio Paraná: aspectos físicos, biológicos e socioeconômicos. Maringá: EDUEM/ Nupélia, 1997. p. 371-394.

SAEED, S.; NAQQASH, M. N.; JALEEL, W.; SAEED, Q.; GHOURI, F. The effect of blow flies (Diptera: Calliphoridae) on the size and weight of mangos (Mangifera indica L.). PeerJ, London, v. 4, p. 1-3, 2016.

SILVEIRA, L. F.; BEISIEGEL, B. M.; CURCIO, F. F.; VALDUJO, P. H.; DIXO, M. VERDADE, V. K.; MATTOX, G. M. T.; CUNNINGHAM, P. T. M. Para que servem os inventários de fauna? Estudos Avançados, São Paulo, v. 24, n. 68, p. 173-207, 2010.

SCHIELEINA, J.; BÖRNERA, J. Recent transformations of landuse and land-cover dynamics across different deforestation frontiers in the Brazilian Amazon. Land Use Policy, Enschede, v. 76, p. 8194, 2018.

SOUSA, J. R.; ESPOSITO, M. C.; CARVALHO-FILHO, F. S.; JUEN, L. The potential uses of sarcosaprophagous flesh flies and blowflies for the evaluation of the regeneration and conservation of forest clearings: a case study in the Amazon forest. Journal of Insect Science, Madison, v. 14, n. 1, p. 1-5, 2014.

SPINDOLA, A. F.; ZHENG, L.; TOMBERLIN, J. K.; THYSSEN, P. J. Attraction and Oviposition of Lucilia eximia (Diptera: Calliphoridae) to Resources Colonized by the Invasive Competitor Chrysomya albiceps (Diptera: Calliphoridae). Journal of Medical Entomology, Madison, v. 54, n. 2, p. 321-328, 2017.

URURAHY-RODRIGUES, A.; RAFAEL, J. A.; PUJOL-LUZ, J. R. Temporal distribution of blowflies of forensic importance (Diptera: Calliphoridae), in man-size domestic pigs' carcasses, in the Forest Reserve Adolpho Ducke, Manaus, Amazonas, Brazil. EntomoBrasilis, Vassouras, v. 6, n. 1, p. 9-22, 2013.

VARGAS, J.; WOOD, D. M. Calliphoridae. In: BROWN, B. V.; BORKENT, A.; CUMMING, J. M.; WOOD, D. M.; WOODLEY, N. E.; ZUMBADO, M. A. (Ed.). Manual of Central American Diptera. Vol. 2. Ottawa: NRC Research Press, 2010. p. 1297-1304. VIANNA, E. E. S.; COSTA, P. R. P.; FERNANDES, A. L.; RIBEIRO, P. B. Abundância e flutuação populacional das espécies de Chrysomya (Diptera, Calliphoridae) em Pelotas, Rio Grande do Sul, Brasil. Iheringia, Série Zoologia, Porto Alegre, v. 94, n. 3, p.231-234, 2004.

WHITWORTH, T. A revision of the Neotropical species of Lucilia Robineau-Desvoidy (Diptera: Calliphoridae), Zootaxa, Auckland, v. 3810, n. 1, p.1-76, 2014.

WHITWORTH, T.; YUSSEFF-VANEGAS, S. A revision of the genera and species of the Neotropical family Mesembrinellidae (Diptera: Oestroidea), Zootaxa, Auckland, v. 4659, n. 1, p. 1-146, 2019. 